Greer, C. (2013) 'Crime and Media: Understanding the Connections' in C. Hale, K. Hayward, A. Wahadin and E. Wincup (eds.) Criminology, third edition, Oxford: Oxford University Press, pp25 (ISBN: 978-0-19-927036-1).

\title{
Crime and media: understanding the connections
}

\author{
Chris Greer
}

\section{INTRODUCTION}

The contemporary era - whether we term it the information society, the network society, the image world, postmodernity, or late modernity - is a fundamentally mediatised era. It is also an era in which high crime rates and high levels of concern about crime have become accepted as 'normal'. The rapid and relentless development of information and communication technologies (ICTS) over the past one hundred years has shaped the modern age, transforming the relations between space, time and identity. Where once 'news' used to travel by ship, it now hurtles across the globe at light speed and is available 24 hours-a-day at the push of a button. Where once cultures used to be more or less distinguishable in national or geographical terms, they now mix, intermingle and converge in a constant global exchange of information. Where once a sense of community and belonging was derived primarily from established identities and local traditions, it may now also be found, and lost, in a virtual world of shared values, meanings and interpretations. In short, the media are not only inseparable from contemporary social life; they are, for many, its defining characteristic. Understanding the connections between crime and the media is central to understanding the cultural place that crime and media occupy in our social world.

This chapter is an introduction to the investigation of crime and media. My main aim is to present a summary of major themes and debates which have shaped the research agenda, but I also want to sharpen the focus of investigation on some less well rehearsed issues such as the changing global communications marketplace, the development of new media technologies, and the significance of these for understanding the connections between crime and media. The chapter is divided into four main sections. The first offers some background information and 
addresses the crucial question of why exploring media images of crime and control is important. The second section considers how scholars have researched crime and media, and presents an overview of the main findings. The third section discusses critically the dominant theoretical and conceptual tools which have been used to understand and explain media representations of crime. The final section considers the evidence for the influence of media representations, both on criminal behaviour and fear of crime. Finally, I will suggest some areas for future research.

\section{BACKGROUND}

Though sections of the popular press may suggest otherwise, most of us have little first-hand experience of serious criminal victimization. Our understanding of the crime problem-how much crime is out there, what types of crime are most prevalent, who is most at risk, what are the best responses-derives mostly from sources other than personal experience. Paramount among these are the media. The media, then, are key producers and purveyors of 'knowledge' about crime, disorder and control. For this reason alone, media representations are worthy of in-depth investigation.

But precisely what kinds of knowledge do these representations generate, and to what effect? Below are some of the key questions which have perplexed students of crime and media:

- Is it possible to discern a coherent picture of 'the crime problem' from the media and, if so, does this picture bear any resemblance to what we may claim, however tentatively, to know of the 'reality' of crime and and criminal justice?

- Do the media merely reflect, objectively and impartially, what happens in the world, or are they active agents in socially constructing 'mediated realities' in which certain values, interests and beliefs are promoted, while others are downplayed, or even actively suppressed?

- Do the media reproduce and reinforce prejudice and the stereotyping of marginalized groups, or actively challenge it?

- Do the media undermine or fortify the existing structures of power and authority?

- Does violence in the media make us more aggressive, more fearful, or both? 
Concern about the pernicious influence of the media is perennial, and academic research exploring media representations of crime dates back to the early 1900s (Pearson, 1983). Yet despite literally thousands of studies, these key questions have generated few conclusive answers. The media are a multiplicity of institutions, organisations, processes and practices which are hugely diverse in composition, scope and purpose. Today there are more media forms (television, newspapers, magazines, radio, the Internet) and greater levels of diversity within each individual form (satellite, cable and digital television) than ever before. Understanding media, therefore, requires a critical and reflexive appreciation both of the diversity of forms and formats involved and of the complexity with which images, texts, messages and signs are produced, transmitted and consumed.

One of the key points to grasp-and one of the issues I want to communicate most forcefully-is that we do not all use, interpret, and respond to media representations in the same way. Images of violent crime, for example, may repel some and attract others, disturb some and excite others, frighten some and anger others. Readers are encouraged to look beyond the instinctive desire to tackle complex dilemmas with simplified accounts and generalizations. The relationship between media images and the world around us is so fascinating precisely because it is complex and hard to pin down.

\section{Researching crime and media}

Research on crime and media covers three principal areas of interest: content; production; and consumption and influence. Each area has its own particular research methods and approaches (Greer, 2010). Media content analysis can be split between studies which are primarily either quantitative or qualitative. Quantitative analyses are concerned first and foremost with measuring the amount of crime, violence or control in the media-for example, the number of crime stories reported in a newspaper, or the number of violent incidents appearing in a television programme. The 'media picture' of crime is then usually compared with the 'real world' picture, normally derived from official criminal statistics. Quantitative approaches traditionally have predominated in research on media content. Qualitative content analyses, by contrast, are concerned primarily with investigating the nature of media representations of 
crime, violence and control. Though they may incorporate some quantitative component, qualitative research is more interested in untangling the complex processes through which media images are produced, exchanged and interpreted-for example, by exploring the use of language, the forces and constraints that shape media production, or the wider influence of the economic, political, moral and cultural environment. Both quantitative and qualitative analyses may be equally concerned with media influence.

Each approach has its strengths and weaknesses, but some of the limitations of purely quantitative research are particularly noteworthy. Official statistics are a very poor indicator of crime rates and may reveal more about the reporting and recording practices of the public and the police than they do about actual levels of offending (Maguire, 2012). Quantitative claims about the relationship between media images and the statistical 'reality' of crime, therefore, need to be treated with caution. More fundamentally, because quantitative analyses cannot tackle the crucial issue of meaning, for many they can only ever provide a surface description of media representations of crime rather than a deeper understanding, which would generally be the favoured research outcome. Nevertheless, quantitative research can offer important insights into changing patterns and trends in the representation of crime, as well as generating useful data on which deeper qualitative investigations can be based.

Content analyses of media representations of crime - whether news, film, television drama, magazine articles or Internet sites - are the key method of establishing 'how' various forms of media represent crime. Content analysis alone, however, cannot explain 'why' media images takes the particular forms that they do. It is only through a focus on media production that representations can be explained. Research on media production is necessarily more qualitative in nature, since it is concerned with the 'social processes' - commercial, political, moral - that shape media content. These processes are too complex to be captured as statistical data. The majority of research has sought to understand media production 'at a distance' by analysing, for example, the 'news values' that determine which crimes are newsworthy and which are not, or the impact of the wider socio-political environment on the representation of crime and justice in film or television drama (Soothill and Walby, 1991; Sparks, 1992; Reiner et al., 2000; Soothill et al., 2002; Seal, 2009). A minority of researchers have sought to understand media 
production 'up close'. In addition to considering the structural determinants of media production and the wider socio-political environment, they have also employed interviews with journalists, editors and producers, police and probation officers, and victims and offenders-and ethnography (for example, exploring crime journalism through shadowing news reporters). The aim here is to gain a deeper, interpretive understanding of media production by engaging directly with those involved in the production process (see Chibnall, 1977; Ericson et al., 1987, 1989, 1991; Schlesinger and Tumber, 1994; Kitzinger and Skidmore, 1995; Greer, 2012).

The third principal area of interest is media consumption and influence. Much media criminology is underpinned by an often implicit assumption of media influence: the media distortion of crime and deviance has a significant impact on society, and this impact is somehow detrimental. On the political right, the concern has been that media glamourise crime and encourage criminality. On the political left, it has been that media increase fear of crime, encouraging political acquiescence to the status quo and strengthening support for authoritarian measures of control and containment. However, with the important exception of studies on media and fear of crime, criminologists have actually conducted very little research to 'evidence' the nature of media influence. Thus there is a fundamental tension within media criminology: much is assumed, but little is researched and evidenced empirically. What research does exist on media consumption and influence has, like content analysis, tended to be quantitative in nature. It has been situated not within sociological criminology, but within a psychological positivism which foregrounds classification ('this is violence, this is not') and counting (the number of violent acts in a given film, newspaper article, website) over a more nuanced, in depth understanding of what media 'mean' to active consumers. Before discussing the pros and cons of this type of research, it is useful to consider in greater detail the content of media representations of crime and control.

\section{The nature and extent of crime in the media}

A virtually universal finding in the literature is that media representations exaggerate both the levels of serious interpersonal crime in society and the risk of becoming a crime victim. This is the case for studies of newspapers (Marsh, 1991), television (Gunter et al., 2003) and radio 
content (Cumberbatch et al., 1995), across both news and entertainment media (Reiner et al., 2000), and literary crime fiction (Knight, 2004). The representation of crime is largely eventoriented in that it focuses on specific criminal cases and incidents rather than wider debates around causes, prevention, or policy (Rock, 1973; Greer, 2012). All media forms focus overwhelmingly on violent or sexual offences.

Calculations of the proportion of news space devoted to crime vary considerably depending on the definition of 'crime' adopted, and the types of material included and excluded on that basis. Some studies, for example, may only include news reports of particular criminal events or court cases (Ditton and Duffy, 1983; Smith, 1984). Others, in addition to considering news reports, may also include feature items, editorial pieces and letters to the editor (Hall et al., 1978; Ericson et al., 1987; Greer and McLaughlin, 2012). Studies may also expand the definition of 'crime' to explore a wider range of deviant acts, such as corporate offending (Cavender and Mulcahy, 1998; Knotterus et al, 2006; Machin and Mayr, 2012), environmental crime (Lynch et al., 2000; Joosse, 2012), and state violence (Cohen, 2002; Herman and Chomsky, 1994). 'Popular' (normally tabloid) news outlets are generally found to include a greater proportion of crime stories reported in a more sensational style than 'quality' (broadsheet) ones (Graber, 1980; Schlesinger et al, 1991). Estimates of the proportion of crime in the UK news media have ranged from 4 per cent in one study (Roshier, 1973) to 13 per cent in another (Williams and Dickinson, 1993). A summary of content analyses in the US found the proportion of crime news to range from just over one per cent, to more than 30 per cent (Marsh, 1991). In the entertainment media, an average of around 25 per cent of US and UK primetime television programming, and around 20 per cent of film releases are crime-centred (Allen et al., 1997).

This section has provided a brief review of the research literature on the content of media representations of crime and criminal justice. The aim of the next section is to establish a clearer picture of the forces and influences that might shape that content.

\section{REVIEW QUESTIONS}

1 Why is it both important and useful to study crime and the media? 
2 What are the main differences between quantitative and qualitative methods of content analysis and what are their respective strengths and weaknesses?

3 Can a coherent picture of the crime problem be discerned from media representations? If so, what is it, and is it accurate?

\section{Theorizing crime and media}

Crime news is not simply plucked out of thin air; nor does it exist in a vacuum. It is the end result of a complex process of selection, processing and prioritization, and is shaped by interactions between journalists, editors, their working conditions, the wider environment and, crucially, news sources. News sources are those individuals, organizations and institutions that provide the information on which journalists often base their stories. In relation to crime news, key sources include the police, probation, prison and court services, politicians, penal reform groups, victim organisations, and a host of other interested parties.

Reporting crime takes time, money and effort. Editors and producers seek to maximize the efficiency and cost-effectiveness of this process by concentrating limited resources around sources that can offer consistently reliable and reportable crime material within the rhythms of the news production process. Powerful criminal justice institutions like the police and the judiciary routinely produce a significant volume of reportable information, and therefore are extremely useful to crime reporters. For this reason, they enjoy what Hall et al. (1978) refer to as 'privileged access' in the media: that is, they usually find it easier than less powerful, or less useful (in news terms), organizations to have their views or version of events publicized. This 'privileged access' is further enhanced by the credibility and cultural authority-the 'expert status' - associated with official agencies on matters of crime and control (Ericson et al., 1989, 1991). That journalists are to an extent reliant on powerful institutional sources is undeniable. The consequences of this reliance, however, and the wider implications for the democratic flow of information and the objectivity and impartiality of the news product, may be interpreted very differently depending on the theoretical approach adopted.

\section{Media theory and crime news production}

Traditional theorizations of news media production can be broadly distinguished according to 
two opposing positions: radical and liberal pluralist. Radical approaches are influenced by the theories of Karl Marx and Antonio Gramsci, among others, and stress the unequal distribution of economic and cultural power throughout society, and its impact on media production. Liberal pluralist interpretations are underpinned by the ideals of classical liberal theory, and emphasize the principles of freedom, choice and democracy, and their impact on media production. There are numerous variations on each perspective, but in their simplest terms, radical readings see the mass media as controlling the people, while liberal pluralist readings see the mass media as serving the people. Some of the most relevant examples of each position are outlined below.

At the radical extreme, the 'propaganda model' views the media as an extension of the State's apparatus of ideological control. Herman and Chomsky have argued that economic, political, military and cultural elites conspire to control the content and flow of media information, filtering out or delegitimizing dissenting views to protect ruling class interests (Herman and Chomsky, 1994). Through analysing news coverage of 'terrorism' and the media's alleged collusion in the 'criminalization' of non-friendly regimes, the authors argue that the key actors in the news production process are not journalists, who are seen as largely powerless, but media owners, who share interests in common with other elite groups. In this critical materialist interpretation the function of the news media is to 'manufacture consent' around elite ideas in the name of the 'national interest' and, in so doing, to engender political compliance and acceptance of the established order.

A less conspiratorial approach is the 'hegemonic model', based on the neo-Marxist writings of Antonio Gramsci (1971). Here the media are viewed not as the direct mouthpieces of the powerful, but as sites of contestation on which alternative viewpoints actively compete for ideological dominance, or hegemony. Due to their privileged access, however, criminal justice institutions are able to advance a 'primary definition' of crime-related issues, which frames the terms for any ensuing debate and subverts competing viewpoints, though these may still be heard, to marginal status (Hall et al., 1978). Journalists may think they are autonomous, but in practice they are constrained to reproduce the elite 'ideas' of the dominant sources on which they rely, in turn helping to make these the 'ideas' of everyone. This is why, it is suggested, 
crime reporting tends to favour an elite (conservative) portrayal of the crime problem-an issue of working-class, minority youth offending (not white collar corruption or state violence), requiring greater punishment and control of particular groups (not government accountability and corporate regulation) (Barlow et al., 1995).

The radical perspective in its various guises contrasts with liberal pluralist media theory (Gans, 1980; Hetherington, 1985). Liberal pluralists concede that certain official interests are advantaged in the media, but they insist that any significant source bias or pressure from media owners is offset by journalistic professionalism, the requirements of objectivity and balance, the ideological and stylistic diversity of the media, and what is viewed as open and equal competition between a wide range of groups for media access and influence. Journalists insist, indeed pride themselves, upon maintaining high levels of professional autonomy and are actively encouraged in this pursuit by colleagues who share the same system of values (Gans, 1980). Any pressure to follow a particular line, apply a particular 'spin', suppress a particular piece of information, or in some other way distort the 'truth status' of the news will be forcefully resisted. Nor does the 'privileged access' of powerful institutions guarantee definitional control. Journalists and other social actors both can and do challenge the established order. This is clear, for example, when the high-profile exposure of scandal (political, sexual, economic) forces senior politicians to resign from office (Thompson, 2000), or the credibility of criminal justice agencies is undermined by media exposés evidencing corruption, incompetence, or institutional racism. In the liberal pluralist view, then, the media expose injustice and hold the powerful to account. They provide a voice for marginalized groups and, in so doing, defend the integrity of the democratic process (Blumler and Gurevitch, 1995).

In practice, the power relations between journalists and sources are more fluid than radical scholars have tended to argue, but more constraining than liberal pluralists suggest (Greer, 2012). With the proliferation of media and the transformation of the information landscape in recent decades, both theoretical approaches have come under fire for being too rigid and deterministic, incapable of capturing the fluidity and unpredictability of power and information flows in multi-mediated societies. Many postmodernists argue that in societies where images, 
signs and codes are constantly recycled through the media, it is no longer possible to distinguish with any certainty between 'image' and 'reality', the 'represented' and the 'real' (Baudrillard, 1983; Poster, 1990); how crime policy is presented becomes more important than what the policy actually is.

The emergence of a highly diversified, 24-7 globalised media environment has changed the terrain upon which struggles over media power and influence are played out. At the national level an already fragmented government struggles to control the crime news agenda, but is repeatedly beaten down by adversarial journalists intent on increasing sales by taking scalps. Rather than routinely controlling the news agenda, Home Secretaries, Police and Crime Commissioners, entire public institutions become the target for press exposés of scandal and corruption (Greer and McLaughlin, 2010, 2012a, 2012b). In a context of declining deference to authority and an increasingly competitive and unpredictable communications marketplace, 'trial by media' becomes a means of journalistic advancement and economic survival (Greer and McLaughlin, 2011, 2013). Dissatisfied and vociferous victims and victim groups now routinely employ professional PR advisers to make the public articulation of their cases more 'mediafriendly', and therefore more widely disseminated. Media audiences, tired of the 'permanent crisis in criminal justice', are actively encouraged to participate in the news production process by emailing, texting or phoning in their views and concerns.

At the global level, faced with ecological disaster, government corruption, police repression, torture and economic meltdown, activists organize themselves into resistance movements and turn increasingly to social media to bring attention to their growing discontent. Facebook is used to schedule protests, Twitter to coordinate events, and the world is simultaneously informed, enthralled and scandalized through YouTube and Wikileaks (Hamm and Greer, 2011). The ongoing military presence in Afghanistan continues to attract moral opprobrium from sections of the press and public, making discursive closure around the 'war on terror' an impossibility. Botched surveillance operations at home are reported alongside the mounting deaths of troops and the abuse of prisoners abroad (Hamm, 2007; Carrabine 2011). In an age of media proliferation, political spin, ubiquitous public relations operatives, and ever-more sophisticated media audiences, communication power may shift from story to story, and the 
balance of definitional influence becomes increasingly unstable and unpredictable.

\section{News values and newsworthiness}

Only a tiny fraction of events, criminal or otherwise, are deemed sufficiently 'newsworthy' to merit media attention. News values are the criteria that determine 'newsworthiness'. They enable journalists and editors to decide which stories to run and which to drop, which are headliners and which are fillers, which are the most important details and which are the least. Having 'a good nose for a story', then, may equally be interpreted as having a well-honed appreciation of news values.

Table 6.1 outlines three different but overlapping interpretations of what it is that make events in general, and criminal events in particular, worthy of media attention.

News values help to explain the broad profile of media representations of crime and control. Interpersonal crimes of sex and violence can be more easily presented as dramatic and titillating than non-violent crimes-for example, most property and white collar offences particularly when they have high levels of proximity (spatial nearness and cultural meaningfulness) to the consumer. By focusing on people (as victims and offenders) and events rather than abstract issues and debates, crime reporting is individualized and simplified, which also contributes to the common association of crime with individual pathology rather than wider social-structural influences. In line with the growth of celebrity culture (Rojek, 2001), crimes are more newsworthy if they involve famous or notable people. Although names will generally be included where possible, one of the most compelling figures in crime stories is the 'unknown' predatory stranger. As the producers of reality television shows like Crimewatch UK or America's Most Wanted and countless newspaper editors know only too well, few stories capture the public imagination as forcefully as the killer on the loose, especially when the (potential) victims are children. In addition to their inherent drama, individualization, violence and proximity, such narratives possess a unnerving sense of immediacy and a palpable risk of further attacks. They have a clear capacity to fulfil that vital, commercially driven journalistic imperative; the requirement to shock (Greer, 2012).

This imperative is increasingly realised by capitalizing on the highly visual nature of contemporary culture (Carrabine, 2012). As the experience of crime and control has become 
more mediatised, so too has it become more image-oriented. Stories are more readily personalized and individualized, they more easily invoke empathy, disdain, shock, when accompanied by visual images. Today 'crime stories are increasingly selected and 'produced' as media events on the basis of their visual (how they can be portrayed in images) as well as their lexical-verbal (how they can be portrayed in words) potential' (Greer, 2007: 29). The availability of an image may determine whether or not a story is run or dropped. The availability of the right image can help elevate a crime victim or offender to national or even global iconic status (Greer and McLaughlin, 2013).

The previous sections have reviewed the literature on the nature and extent of representations of crime and control in the media, and offered an overview of some of the main theoretical and conceptual tools used to understand why media representations take on the form that they do. The next section considers the evidence for media influence and effects.

\section{REVIEW QUESTIONS}

1 What are the principal characteristics of the radical and liberal pluralist readings of news production? How does each reading view journalistic freedom and source power?

2 How useful are radical and liberal pluralist approaches to understanding media in an age of media proliferation, diversification and saturation?

3 What is it that makes some crimes so eminently reportable, while others are scarcely mentioned?

\section{Problematizing crime and media}

Few today would suggest that media representations have no influence on their audiences. Rather, the debate is about the nature, extent and significance of that influence. As noted above, the concern on the political right has been that media images glamorize crime and violence, undermining respect for authority and the rule of law and encouraging criminality. On the left it has been that media images of crime and deviance increase public fears and anxieties, helping to win support for authoritarian measures of control and containment. 


\section{Media violence and the problem of 'effects'}

Research on media effects has for decades sought to demonstrate a causal relationship between media violence and violent thoughts and behaviours in the real world. Typically, subjects (most often children) are exposed to some aggressive stimulus (say, a short violent film) within a controlled setting (frequently a laboratory or office), and then observed to see if they think or behave more aggressively than a control group not exposed to the aggressive stimulus (Bandura et al., 1963 is the classic experimental design). Myriad variations have been conducted on this 'stimulus-response' format, variously controlling for participant characteristics, type of violence shown, duration of exposure, whether the violence is punished or rewarded, and so on. In a frequently quoted statistic, more than 70 per cent of studies claim to demonstrate that media violence does cause real life violence (Andison, 1977; Howitt, 1998).

Such 'evidence' of criminogenic media effects is regularly cited by right-wing moral campaigners as justification for greater controls and censorship. However, effects research has been heavily criticized on methodological, theoretical and conceptual grounds. Gauntlett (2001), and others (Livingstone, 1996; Greer and Reiner, 2012), have identified a number of problems with the 'effects model'. Some of the most pertinent are summarized below.

- Counting 'units' of violence in accordance with the pre-established definitions of the researcher ('this is violence, this is not'), ignores the different meanings that people attach to acts and behaviours and implicitly assumes not just that we all think the same way, but that we all think the same way as the researcher.

- It is dubious to suppose that how subjects behave in controlled experimental environments (where they know they are being observed), sometimes toward inanimate objects (for example, an inflatable doll), reflects how they will behave in the real world toward real people.

- There is an assumption that only certain types of person are susceptible to the influence of media violence-mostly children, who are considered helpless victims, but sometimes also 'uneducated' or 'working class' populations, who apparently lack the maturity and sense most people take for granted. 
- Different forms of violence-for example, in cartoons, soap operas, and horror moviesare often conflated, treated as equal in weight, and reduced to statistical data lacking any sense of plot or context. Whether violence is rewarded or punished, realistic or humorous, perpetrated by a 'hero' or a 'villain', may influence its impact profoundly.

- A correlation-violent people enjoy violent media-is not the same as a causal relationship-people are violent because of violent media. Media representations may provide technical knowledge about committing violent crimes, but that does not mean they also motivate people to use it.

- Whether intended or not, effects studies play into the hands of moral conservatives who wish simplistically to blame the media for society's ills, rather than addressing more intractable sources of crime like social inequality.

- Media influence, short-term or cumulative, can never be disaggregated entirely from other social, psychological and cultural influences, yet studies routinely search for a 'pure' (negative) media effect. Pro-social images, though rarely considered, may be just as powerful as anti-social ones, and perhaps even more so.

While psychological positivism searches for direct 'media effects' on more or less 'passive subjects', sociological and media researchers focus on media use and interaction among 'active consumers'. Here, the reception and interpretation of media images are considered, not in isolation, but as part of an ongoing process of interaction, both with other media forms and with the 'material and social realities of people's lives' (Kitzinger, 1999: 11; Hunt, 1997; Buckingham, 2000). Kitzinger (2004) has conducted in depth interviews and focus groups with media practitioners, interest groups and consumers to explore the role of media representations in shaping understanding of sex crime as a contemporary social problem. With the development of 'creative methods' in media studies (Buckingham, 2009), researchers empower young people by allowing them to illustrate with the use of new media technologies how violence - on TV, in the playground, in the news - differentially shapes their experiences on a daily basis (Myers and Thornham, 2012). 


\section{Media and fear of crime}

Fear of crime first registered on the policy agenda in the early 1980s, when the British Crime Survey suggested it was becoming as big a problem as crime itself (Hough and Mayhew, 1983). Its consequences may range from not walking home alone at night to withdrawing from society altogether (Ferraro, 1995). Given the centrality of fear of crime in the public and political imagination, understanding its origins is an important criminological undertaking. Fear of crime is influenced by a range of social and demographic variables-perceptions of risk and vulnerability, age, social class, geographical location, ethnicity, and experience of criminal victimization (Box et al., 1988; Hale, 1996). Media representations, though enormously diverse, are only one possible influence among many. As such, their significance remains a matter for debate.

Probably the best known research in this area is the 'cultivation analysis' of Gerbner et al., which over several decades has employed content analyses and survey questionnaires to assess quantitatively the influence of violence on prime-time US television (Gerbner and Gross, 1976; Gerbner et al., 1994). The central finding is that 'heavy' television viewers (those who watch most TV-more than four hours per day in Gerbner's studies) cultivate a world-view which more closely resembles the 'television message' than 'light' television viewers (those who watch less than two hours per day). Because television overstates both the seriousness and risk of criminal victimization, portraying the world as 'mean and scary', heavy viewing is said to cultivate higher fear of crime. Fearful citizens, it is argued, tend to be depoliticised, more dependent on established authority, more punitive, and more likely to acquiesce to authoritarian measures of control.

While supported in some studies (Hawkins and Pingree, 1980; Morgan, 1983), others have failed to replicate the cultivation effect (Gunter, 1987; Cumberbatch, 1989), and a number of empirical and theoretical weaknesses have been identified, including: the simplification and decontextualising of the categories 'media', 'violence' and 'fear'; the attempts to quantify the creative and highly variable processes of interpretation and influence; and the search for a straightforward causal connection between media and fear of crime (Sparks, 1992; Ditton et al, 2004). Though more recent studies, including revised work by Gerbner, have sought to address 
these shortcomings, evidence for an isolated 'cultivation effect' remains inconclusive.

Exploring the extent to which images of crime and violence resonate with consumers' lives appears crucial to understanding their impact. Schlesinger et al. (1992), for example, found that women may be particularly sensitive to images of interpersonal attacks. Partly on this basis, concerns have been expressed that the highly unrepresentative focus on 'real' violent and sexual interpersonal crimes in the BBC's long running reality show Crimewatch UK may increase levels of fear in sections of the viewing audience (Jewkes, 2011). Research on US television news concluded that local crime coverage generates more fear than national coverage, particularly within individuals who have experienced victimization and perceive television accounts to be realistic (Chiricos et al., 2000; see also Eschholz et al., 2003). Ditton et al's (2004: 607), combination of quantitative questionnaires and qualitative interviews revealed that it is not the 'objectively determined randomness, localness or sensationalism that is important, but rather the interpretation of media content as relevant to and by the consumer'. Finally, some have questioned the tendency to characterise fear of crime in purely negative terms, and asked if some level of 'functional fear' - as opposed to 'dysfunctional worry' - might in fact be 'a motivating force that encourages vigilance and stimulates precautionary activity', such as taking additional measures to safeguard one's self and personal belongings(Jackson and Gray, 2010).

\section{Moral panics and multi-mediated societies}

The term 'moral panic' refers to the disproportionate and hostile social reaction to a group or condition perceived as a threat to societal values. It involves sensational and stereotypical media coverage, public outcry and demands for tougher controls. As the name suggests, the panic may subside as rapidly as it erupted. Moral panics have most often emerged around youth-related issues, particularly subcultural expressions of identity-for example, punk, rave and the wider drugs culture-but football hooliganism, the re-housing of sex offenders in the community and terrorism have also been the source of recent panic (Jenkins, 1992; Silverman and Wilson, 2002; Cohen, 2011).

In the original analysis, Cohen (1972) problematised the social reaction to the Mods and Rockers disturbances in 1964, when boredom and bad weather one Bank Holiday resulted in a few fights, lots of noise and some windows being smashed. Though the damage was minor, the 
national press exaggerated and sensationalized the disturbances using phrases like 'day of terror' and 'hell-bent on destruction'. News reports predicted further violence, demanded tighter controls, and portrayed Mods and Rockers as 'folk devils' - a symbol not just of youth delinquency, but of wider permissiveness and social decline. Cohen (1972) demonstrates how the labelling and marginalization of Mods and Rockers and the emphasis on mutual antagonism created a 'deviancy amplification spiral' that resulted in further disturbances. These disturbances seemed to justify initial fears, resulting in more media coverage, more public outcry, more policing, and thus the spiral of reaction and deviancy amplification continued. The moral panic occurred at a time of rapid social change. In particular, the increase in youth spending power and sexual freedom, defiantly flaunted by young people, blurred moral and class boundaries and challenged the traditional ethics of hard work and sobriety, generating resentment and hostility among 'respectable society'. The 'creation' of Mods and Rockers provided scapegoats or 'folk devils'-a deviant minority against whom the conforming (nostalgically reactionary, adult) majority could unite at a time of uncertainty, conflict and change.

In a radical, Gramscian analysis of 'hegemonic crisis' at a time of economic recession, political decline and class unrest in 1970s Britain, Hall et al. (1978) argue that the State orchestrated a moral panic around 'mugging', and cast the young black street criminal in the central role. The creation of this 'folk devil', again providing a unifying focus for 'respectable' outrage, tapped into escalating fears around crime, race and social decline, and allowed the State to reassert and relegitimate itself-'policing the crisis', crucially with public consent, by stamping down hard on the problem from above (see Crime, Media, Culture, 2010, 4,1; 2012, 7,3).

Critics of moral panic theory have questioned the attribution of 'disproportionality' to the social reaction because this assumes a superior knowledge of both the objective reality of the issue and of what a 'proportionate' reaction would look like (Waddington, 1986). Left realists (see Chapter 3), in committing to 'take crime seriously', insisted that crime and fear of crime cannot simply be dismissed as groundless media-induced hysteria (Matthews and Young, 1992). Others have gone further, suggesting that in multi-mediated, risk societies the concept of moral panic needs to be reformulated (McRobbie and Thornton, 1995; Garland, 2008). While folk 
devils were once helpless against their demonization, they may now find themselves being vociferously supported in the same media that castigate them. In the chaotic 24-7 global mediasphere, they may also provide counter-definitions and explanations in any number of alternative media outlets. While moral panics were once rare, they are now commonplace, and even commercially desirable. One of the best ways of promoting (and selling) records, clothes, books, films-most popular cultural commodities, in fact-is to court controversy and proactively generate a little 'panic'.

\section{REVIEW QUESTIONS}

1 What does the 'effects' model propose, and how has effects research been criticized?

2 Compile a list of factors, other than media representations, which might influence fear of crime, and rank them in order of importance.

3 Can you think of any recent moral panics? On what basis would you say that the term 'moral panic' is sociologically justified in these instances?

\section{Contemporary dimensions in crime and media}

Today, sensational crime and justice events are webcast as they happen, high-profile 'celebrity' trials are tweeted live, riots and revolutions are orchestrated with social media, and the growth in 'reality' programming continues to erode the boundaries between news and entertainment, fact and fiction. From the 'live broadcast' destruction of New York's twin towers on 11 September, 2001 (Castells, 2004), through the 'shock and awe' invasions of Afghanistan and Iraq (Ullman and Wade, 1996), to the carefully 'staged and scripted' executions of Western kidnap victims (Ferrell et al, 2005), global conflicts have become hyper-mediatised contests of strike and counter-strike, claim and counter-claim, in a manner unimaginable in the industrial modern era. As Castells (2004: 139) argues, 'The media, local and global, are the means of communication through which the public mind is formed. Therefore, action has to be mediaoriented, it has to be spectacular, provide good footage, so the whole world can see it: like a Hollywood movie because this is what has trained the human mind in our times.'

This process of hyper-mediatisation extends to other spheres of crime and criminal justice, in turn looping back to connect again with defining $21^{\text {st }}$ Century fears and insecurities. With 
millions of operational surveillance cameras, the UK has the dubious distinction of containing the highest ratio of CCTV cameras to people anywhere in the world (Home Affairs Committee, 2008). While some level of surveillance is necessary for the smooth running of any democracy for example, postal services and electoral systems could not function without an up-to-date record of every citizen's name and address - the exponential increase in surveillance has generated concerns about the erosion of civil liberties and the boundaries between public and private in a 'surveillance society' (Doyle et al., 2011; Norris and Armstrong, 1999; McCahill, 2002). Considered alongside the massive growth in personal data gathering in the private and public sectors - travel, credit, store loyalty and identity cards; mobile phones; online banking, shopping and social networking facilities; predictive customer profiling systems - the benefits of surveillance cannot eclipse its potential problems. There are real risks of data loss and abuse by those in power, the criminal appropriation of confidential personal information, and the data-driven stereotyping of whole sections of society (Coleman, 2005; Lyon, 2009). Such stereotyping spans the spectrum of deviance, from controlling everyday youthful transgression by banning hooded tops or 'hoodies' from shopping centres (Hayward and Yar, 2006), to the ongoing 'war on terror' (Mythen and Walklate, 2006).

Globalised access to the Internet generates unprecedented opportunities for social networking and the creation of virtual communities (Greer, 2004), but also new forms of criminality and criminal victimisation. The spread of hate sites (Franko Aas, 2006), cyberstalking (Wykes, 2007), viral victimisation (Brown, 2003), cyberbullying (Shariff, 2008) and the online 'grooming' and sexual abuse of children (Martellozzo, 2012), have all come under the criminological gaze. Across the 24-7 global mediasphere, the conceptualization, definition and experience of crime and control are changing. The challenge is for media criminologists to keep up.

\section{CONCLUSION}

This chapter has provided an overview of some of the main issues and debates that continue to inform the scholarly investigation of crime and media. You should now have a sense of the nature and extent of crime, violence and control in media content, an understanding of some of the dominant theoretical and conceptual tools used to explain and understand media 
representations, a working knowledge of the evidence for and against media effects, and an awareness of new developments in crime and media research. Equipped with this knowledge and insight, you can now explore in greater detail any issues which have challenged your assumptions, tested your critical faculties, or stimulated your imagination.

Today, image and representation penetrate all areas of social existence. Media tap into and reinforce social and political concerns. They help shape individual and collective identities, sensibilities, fears, anxieties and appetites. They provoke public outcry and, at times, generate moral panics. They serve as ideological weapons in the ongoing struggle for hegemony. They impart important but often mixed messages about the nature and extent of 'the crime problem', how we should think and feel about it, who is most at risk, and what is to be done. They indicate, however inaccurately, the state of the nation, but they also entertain. 'Crime talk' (Sasson, 1995), in whatever form, simultaneously elicits fear and fascination; it is a major source of concern, but also of distraction, resistance, escapism, and moral reassurance (Sparks, 1992; Ferrell et al, 2008). Crime sells. It always has.

Whether as news, fiction, or that expanding cultural form that lies somewhere in between, the sheer quantity of crime in the media illustrates that we have an insatiable appetite for narratives of deviance and control. And there is evidence to suggest we are growing hungrier (Reiner et al., 2000). Given the close interrelationship between the political, commercial and cultural significance of crime and disorder, it is small wonder it features so prominently across all media and markets. As the boundaries between fact and fiction (the represented and the real) become increasingly diffuse and uncertain, so the importance of understanding the connections between crime and the media becomes more concrete.

\section{QUESTIONS FOR DISCUSSION}

1 Design and conduct your own content analysis of newspaper crime reporting. Make sure you include quantitative and qualitative considerations and consider both words and images.

2 Compare coverage of the same crime or justice event in at least three different media forms (newspaper, Internet, television, radio, Twitter). How and why does representation differ between media forms?

3 Watch an episode of your favourite crime drama or a recent film and note the portrayal of 
policing and criminal justice. Are the representations favourable or critical?

4 Keep a 'crime diary' for a week and record your thoughts and feelings about crime and personal safety. Do media representations have any impact on your fear of crime?

5 Compile a list of all the ways in which you are subject to surveillance in a typical day.

\section{GUIDE TO FURTHER READING}

Greer, C. (2010) Crime and Media: A Reader. London: Routledge.

This book provides the only comprehensive collection of key and classic readings on crime and media in one volume.

Jewkes, Y. (2011) Media and Crime, second edition, London: Sage.

This highly accessible textbook offers a book length analysis of many of the issues discussed in the chapter you have just read.

Greer, C. and Reiner, R. (2012) 'Mediated Mayhem: Media, Crime and Criminal Justice', in M. Maguire, R. Morgan and R. Reiner (eds) The Oxford Handbook of Criminology (5th edn). Oxford: Oxford University Press.

An alternative overview of many of the issues covered in this chapter.

Cohen, S. (2002) Folk Devils and Moral Panics: The Creation of Mods and Rockers, third edition, London: Routledge.

This classic text presents the original development of 'moral panic' - one of the most widely used (and often misused) concepts in the sociology of deviance, crime and social control.

Crime, Media, Culture: An International Journal, London: Sage

This international journal provides a forum for researchers working at the interface between 
criminology, media studies and cultural studies.

\section{WEB LINKS}

http://www.lexisnexis.com

Lexis Nexis is a useful resource for searching news and other print media from around the world. However, beware that data are returned structure, style and image free. Use LexisNexis to locate the coverage. Then go get the original copy to research it!

http://www.ccms-infobase.com

The Communication, Cultural and Media Studies Infobase contains a wide range of salient links, definitions, and issues for debate-pitched at an introductory undergraduate level-which are easy to navigate.

Web of knowledge Accessible through most university websites, the Web of Knowledge is one of the most comprehensive searchable databases for scholarly research articles on a host of topics, including crime and media. The web address varies depending on the University system being used to access it.

Newspaper and news websites Literally thousands of news websites provide a rich source of data for news media criminologists to conduct content and semiotic analyses of crime reporting.

\section{REFERENCES}

Allen, J., Livingstone, S. and Reiner, R. (1997) 'The Changing Generic Location of Crime in Film: A Content Analysis of Film Synopses', Journal of Communication, 47: 89-101.

Andison, E. (1977) 'TV Violence and Viewer Aggression: A Cumulation of Study Results, 19561979', Public Opinion Quarterly, 41, 3: 314-31.

Bandura, A., Ross, D. and Ross, S. (1963) 'Imitation of Film-Mediated Aggressive Models', Journal of Abnormal and Social Psychology, 66: 3-11. 
Barlow, M., Barlow, D. and Chiricos, T. (1995) 'Economic Conditions and Ideologies of Crime in the Media: A Content Analysis of Crime News', Crime and Delinquency, 41, 1: 3-19.

Baudrillard, J. (1983) 'The Precession of the Simulacra', in T. Doherty (ed) The Postmodern Reader. Hemel Hempstead: Harvester Press.

Blumler, J. and Gurevitch, L. (1995) The Crisis of Public Communication. London: Routledge.

Box, S., Hale, C. and Andrews, G. (1988) 'Explaining Fear of Crime', British Journal of Criminology, 28: 340-56.

Brown, S. (2003) Crime and Law in Media Culture. Buckingham: Open University Press.

Buckingham, D. (2000) The Making of Citizens: Young People, News and Politics. London: Routledge.

Buckingham D (2009) 'Creative' visual methods in media research: possibilities, problems and proposals. Media, Culture \& Society, 31, 4: 633-652.

Carrabine, E. (2012) 'Just Images: Aesthetics, Ethics and Visual Criminology', British Journal of Criminology, 52, 3: 463-489.

Carrabine, E. (2011) 'Images of Torture: Culture, Politics and Power', Crime, Media, Culture, 7, 1: 5-30.

Castells, M. (2004) The Power of Identity (2nd edn). Oxford: Blackwell.

Cavender, G. and Mulcahy, A. (1998) 'Trial by Fire: Media Constructions of Corporate Deviance', in Justice Quarterly, 15, 4: 697-719.

Chermak, S. (1995) Victims in the News: Crime and the American News Media. Boulder, CO: Westview Press.

Chibnall, S. (1977) Law and Order News: An Analysis of Crime Reporting in the British Press. London: Tavistock.

Chiricos, T., Padgett, K. and Gertz, M. (2000) 'Fear, TV News, and the Reality of Crime', Criminology, 38, 3: 755-85.

Cohen, S. (2011) 'Whose side were we on? The undeclared politics of moral panic theory', Crime Media Culture, 7, 3: 237-243.

Cohen, S. (1972) Folk Devils and Moral Panics: The Creation of the Mods and Rockers. London: MacGibbon and Kee. 
Cohen, S. and Young, J. (eds) (1981) The Manufacture of News: Social Problems, Deviance and Mass Media, revised edition. London: Constable.

Coleman, R. (2005) 'Surveillance in the City: Primary Definition and Urban Spatial Order', Crime, Media, Culture: An International Journal, 1, 2: 131-148.

Cumberbatch, G. (1989) 'Violence in the Media: The Research Evidence', in G. Cumberbatch and D. Howitt (eds) A Measure of Uncertainty: the Effects of the Mass Media. London: John Libbey. Cumberbatch, G., Woods, S. and Maguire, A. (1995) Crime in the News: Television, Radio and Newspapers: A Report for BBC Broadcasting Research. Birmingham: Aston University, Communications Research Group.

Ditton, J., Chadee, D., Farrall, S., Gilchrist, E. and Bannister, J. (2004), 'From Imitation to Intimidation: A Note on the Curious and Changing Relationship Between the Media, Crime and Fear of Crime', British Journal of Criminology, 44, 4: 595-610.

Ditton, J. and Duffy, J. (1983) 'Bias in the Newspaper Reporting of Crime', British Journal of Criminology, 23, 2: 159-65.

Doyle, A., Lippert, R. and Lyon, D. (2011) Eyes Everywhere: The Global Growth of Camera Surveillance, London: Routledge.

Ericson, R., Baranek, P. and Chan, J. (1987) Visualising Deviance: A Study of News Organisation. Milton Keynes: Open University Press.

Ericson, R., Baranek, P. and Chan, J. (1989) Negotiating Control: A Study of News Sources. Milton Keynes: Open University Press.

Ericson, R., Baranek, P. and Chan, J. (1991) Representing Order: Crime, Law and Justice in the News Media. Milton Keynes: Open University Press.

Eschholz, S., Chiricos, T. and Gertz, M. (2003) 'Television and Fear of Crime: Programme Types, Audience Traits and the Mediating Effect of Perceived Neighbourhood Racial Composition', Social Problems, 50, 3: 395-415.

Ferraro, K. (1995) Fear of Crime: Interpreting Victimisation Risk. New York: State University of New York, Albany.

Ferrell, J., Hayward, K. and Young, J. (2008) Cultural Criminolgoy: An Invitation, London: Sage. Ferrell, J., Greer, C. and Jewkes, Y. (2005) 'Hip Hop Graffiti, Mexican Murals, and the War on 
Terror', in Crime Media Culture: An International Journal, 1, 1: 5-9.

Franko Aas, K. (2006) 'Governance and the Internet', in Y. Jewkes (ed.) Crime Online, Cullompton: Willan.

Galtung, J. and Ruge, M. (1965) 'Structuring and selecting news', in S. Cohen and J. Young (eds) (1981), The Manufacture of News: Deviance, Social Problems and the Mass Media, revised edition. London: Constable.

Gans, H. (1980) Deciding What's News. London: Constable.

Garland, D. (2008) 'On the Concept of Moral Panic', Crime, Media, Culture: An International Journal, 4, 1: 9-30.

Gauntlett, D. (2001) 'The Worrying Influence of "Media Effects" Studies', in M. Barker and J. Petley (eds) (2001) III Effects: The Media/Violence Debate (2nd edn). London: Routledge.

Gerbner, G. and Gross, L. (1976) 'Living with Television: the Violence Profile', Journal of Communication, 26, 1: 173-99.

Gerbner, G., Gross, L., Morgan, M. and Signorielli, N. (1994) 'Growing up with Television; The Cultivation Perspective', in J. Bryant and D. Zillman. (eds) Media Effects. Hillsdale, NJ: Lawrence Erlbaum.

Graber, D. (1980) Crime, News and the Public. New York: Prager.

Gramsci, A. (1971) Selections from the Prison Notebooks. London: Lawrence and Wishart.

Greer, C. (2012) Sex Crime and the Media: Sex Offending and the Press in a Divided Society, London: Routledge.

Greer, C. (2010) Crime and Media; A Reader, London: Routledge.

Greer, C. (2007) 'News Media, Victims and Crime', in P. Davies, P. Francis and C. Greer (eds) Victims, Crime and Society. London: Sage

Greer, C. (2004) 'Crime, media and community: grief and virtual engagement in late modernity', in J. Ferrell, K. Hayward, W. Morrison and M. Presdee (eds) Cultural Criminology Unleashed. London: Cavendish.

Greer, C. and Jewkes, Y. (2005) 'Extremes of Otherness: Media Images of Social Exclusion', Social Justice (special edition on Emerging Imaginaries of Regulation, Control and Oppression), 32, 1: 20-31. 
Greer, C. and McLaughlin, E. (2013) 'Media Justice: Madeleine McCann, Intermediatisation and 'Trial by Media' in the British Press', Theoretical Criminology, 17, 1.

Greer, C. and McLaughlin, E. (2012) 'This is not Justice: Ian Tomlinson, Institutional Failure and the Press Politics of Outrage', in British Journal of Criminology, 52, 2: 274-293.

Greer, C. and McLaughlin, E. (2011) 'Trial by Media: Policing, the 24-7 News Mediasphere, and the Politics of Outrage', Theoretical Criminology, 15, 1: 23-46.

Greer, C. and McLaughlin, E. (2010) 'We Predict a Riot: Public Order Policing, New Media Environments and the Rise of the Citizen Journalist', in British Journal of Criminology, 50, 6: 1041-1059.

Greer, C. and Reiner, R. (2012) 'Mediated Mayhem: Media, Crime and Criminal Justice', in M. Maguire, R. Morgan and R. Reiner (eds.) Oxford Handbook of Criminology, $5^{\text {th }}$ edition, Oxford: Oxford University Press.

Gunter, B. (1987) Television and the Fear of Crime. London: John Libbey.

Gunter, B., Harrison, J. and Wykes, M. (2003) Violence on Television: Distribution, Form, Context and Themes. London: Lawrence Erlbaum.

Hale, C. (1996) 'Fear of Crime: A Review of the Literature', International Review of Victimology, 4, 2: 79-150.

Hall, S. Critcher, C. Jefferson, T. Clarke, J. and Roberts, B. (1978) Policing the Crisis: Mugging, the State and Law and Order. London: Macmillan.

Hamm, M. (2007) 'High Crimes and Misdemeanors: George Bush and the Sins of Abu Ghraib', in Crime, Media, Culture: An International Journal, 3, 3,: 259-284.

Hamm, M. and Greer, C. (2011) 'Into the Future Darkly', in Crime Media Culture: An International Journal, 7, 1,: 3-4.

Hawkins, R. and Pingree, S. (1980) 'Some Processes in the Cultivation Effect', in Communication Research, 7, 2: 193-226.

Hayward, K. and Yar, M. (2006) 'The 'Chav' Phenomenon: Consumption, Media and the Construction of a New Underclass', in Crime. Media, Culture: An International Journal, 2, 1: 928.

Herman, E. and Chomsky, N. (1994) Manufacturing Consent: The Political Economy of the Mass 
Media. New York: Pantheon.

Hetherington, A. (1985) News, Newspapers and Television. London: Macmillan.

Hough, M. and Mayhew, P. (1983) The British Crime Survey, Home Office Research Study 76. London: HMSO.

Howitt, D. (1998) Crime, the Media and the Law. London: Wiley.

Hoyle, C. (2012) 'Victims, the Criminal Process, and Restorative Justice', in M. Maguire, R. Morgan and R. Reiner (eds) The Oxford Handbook of Criminology (5th edn). Oxford: Oxford University Press.

Hunt, D. (1997) Screening the Los Angeles 'Riots', New York: Cambridge University Press. Jackson, J. and Gray, E. (2010) 'Functional Fear and Public Insecurities About Crime', in British Journal of Criminology, 50, 1: 1-22.

Jenkins, P. (1992) Intimate Enemies: Moral Panics in Contemporary Great Britain. Hawthorne, NY: Aldine de Gruyter.

Jewkes, Y. (2002) Captive Audience: Media, Masculinity and Power in Prisons. Cullompton: Willan.

Jewkes, Y. (ed) (2003) Dot. Cons: Crime, Deviance and Identity on the Internet. Cullumpton: Willan.

Jewkes, Y. (2011) Media and Crime. $2^{\text {nd }}$ Ed., London: Sage.

Joosse, P. (2012) 'Elves, environmentalism, and "eco-terror": Leaderless resistance and media coverage of the Earth Liberation Front' Crime, Media, Culture, 8, 1: 75-93.

Kitzinger, J. (2004) Framing Abuse: Media Influence and Public Understanding of Sexual Violence Against Children, London: Pluto.

Kitzinger, J. (1999) 'A sociology of media power: key issues in audience reception research', in G. Philo (ed) Message Received. London: Longman.

Kitzinger, J. and Skidmore, P. (1995) 'Child Sexual Abuse and the Media', Summary Report to ESRC. Award no. R000233675. Report available from Glasgow Media Group.

Knight, S. (2004) Crime Fiction 1800-2000. Basingstoke: Palgrave Macmillan.

Knotterus, D., Ulsperger, J., Cummins, S. and Osteen, E. (2006) 'Exposing Enron: Media Representations of Ritualised Deviance in Corporate Culture' Crime, Media, Culture: An 
International Journal, 2, 2: 177-195.

Livingstone, S. (1996) 'On the Continuing Problem of Media Effects', in J. Curran and M. Gurevitch (eds) Mass Media and Society. London: Arnold.

Lynch, M., Stretesky, P. and Hammond, P. (2000) 'Media Coverage of Chemical Crimes, Hillsborough County, Florida, 1987-1997', British Journal of Criminology, 40, 1: 112-26.

Lyon, D. (2009) Identifying Citizens: ID Cards as Surveillance, Cambridge: Polity.

Machin, D. and Mayr, A. (2012) 'Corporate Crime and The Discursive Deletion Of Responsibility:

The Case Study of The Paddington Rail Crash', Crime, Media, Culture: An International Journal, 8, 3: 63-82.

Maguire, M. (2012) 'Criminal Statistics and the Construction of Crime', in M. Maguire, R. Morgan and R. Reiner (eds) The Oxford Handbook of Criminology (5th edn). Oxford: Oxford University Press.

Manning, P. (2001) News and News Sources: A Critical Introduction. London: Sage.

Marsh, H.L. (1991) 'A Comparative Analysis of Crime Coverage in Newspapers in the United States and Other Countries From 1960-1989: A Review of the Literature', in Journal of Criminal Justice, 19, 1: 67-80.

Martellozzo, E. (2012) Online Child Sexual Abuse: Grooming, Policing and Child Protection in a Multi-Media World, London: Routledge.

Matthews, R. and Young, J. (1992) (eds) Rethinking Criminology: the Realist Debate. London: Sage.

McCahill, M. (2002) The Surveillance Web: The Rise of Visual Surveillance in an English City. Cullompton: Willan.

McNair, B. (2009) News and Journalism in the UK (5th edn). London: Routledge.

McRobbie, A. and Thornton, S. (1995) 'Rethinking "Moral Panic" for Multi-Mediated Social Worlds', British Journal of Sociology. 46, 4: 559-74.

Miller, D. (1993) 'Official Sources and "Primary Definition": The Case of Northern Ireland', Media, Culture and Society, 15, 3: 385-406.

Morgan, M. (1983) 'Symbolic Victimisation and Real World Fear', in Human Communication Research, 9, 2: 146-57. 
Mythen, G. and Walklate, S. (2006) 'Communicating the Terrorist Risk: Harnessing a Culture of Fear', in Crime, Media, Culture: An International Journal, 2, 2: 123-142.

O'Connell, M. and Whelan, J. (1996) 'The Public Perceptions of Crime Prevalence, Newspaper Readership and “Mean World" Attitudes' in Legal and Criminal Psychology. 1, 2: 179-95.

Pearson, G. (1983) Hooligan: A History of Respectable Fears. London: Macmillan.

Poster, M. (1990) The Mode of Information: Poststructuralism and Social Context. Cambridge: Polity Press.

Potter, W., Vaughan, M., Warren, R., Howley, K., Land. A. and Hagemeyer, J. (1997) 'Aggression in Television Entertainment: Profiles and Trends', Communication Research Reports, 14, 1: 116-24.

Reiner, R., Livingstone, S. and Allen, J. (2000) 'Casino culture: media and crime in a winner-loser society' in K. Stenson and D. Cowell (eds) Crime, Risk and Justice. Cullumpton: Willan.

Rock, P. (1973) 'News as eternal recurrence' in S. Cohen and J. Young (eds) (1981) The Manufacture of News: Social Problems, Deviance and the Mass Media, revised edition. London: Constable.

Rojek, C. (2001) Celebrity (FOCI) London: Reaktion Books.

Roshier, R. (1973) 'The Selection of Crime News by the Press', in S. Cohen and J. Young (eds) (1981) The Manufacture of News: Deviance, Social Problems and the Mass Media, revised edition. London: Constable.

Sasson, T. (1995) Crime Talk: How Citizens Construct Social Problems. Howthorne, NY: Aldine de Gruyter.

Schlesinger, P., Dobash, R.E., Dobash, R. and Weaver, C.K. (1992) Women Viewing Violence. London: British Film Institute.

Schlesinger, P. and Tumber, H. (1994) Reporting Crime: The Media Politics of Criminal Justice. Oxford: Clarendon Press.

Schlesinger, P., Tumber, H. and Murdock, G. (1991) 'The Media Politics of Crime and Criminal Justice', British Journal of Sociology, 42, 3: 397-420.

Seal, L. (2009) 'Issues of Gender and Class in the Mirror Newspaper's Campaign for the Release of Edith Chubb', Crime Media Culture, 5, 1: 57-78. 
Shariff, S. (2008) Cyberbullying: Issues and Solutions for the School the Classroom and the Home, London: Routledge.

Silverman, J. and Wilson, D. (2002) Innocence Betrayed: Paedophilia, the Media and Society. Cambridge: Polity Press.

Smith, S. (1984) 'Crime in the News', in British Journal of Criminology, 24, 3: 289-95.

Soothill, K. and Walby, S. (1991) Sex Crime in the News. London: Routledge.

Soothill, K., Peelo, M., Francis, B., Pearson, J. and Ackerley, E., (2002) 'Homicide and the Media: Identifying the Top Cases in The Times', Howard Journal of Criminal Justice, 41,5: 401-421.

Sparks, R. (1992) Television and the Drama of Crime: Moral Tales and the Place of Crime in Public Life. Buckingham: Open University Press.

Thompson, J.B. (2000) Political Scandal: Power and Visibility in the Media Age. Cambridge: Polity.

Waddington (1986) 'Mugging as a Moral Panic: A Question of Proportion', in British Journal of Sociology, 37, 2: 245-59.

Williams, P. and Dickinson, J. (1993) 'Fear of Crime; Read All About It; The Relationship Between Newspaper Crime Reporting and Fear of Crime', in British Journal of Criminology, 33, 1: 33-56.

Winston, R. (2004) 'Seeing is Believing', in The Guardian, G2, 7 January, 2004. Wykes, M. (2001) News, Crime and Culture. London: Pluto Press.

Wykes, M. (2007) 'Constructing Crime: Culture, Stalking, Celebrity and Cyber', in Crime, Media, Culture: An International Journal, 3, 2: 158-174.

Figure 6.1 A Sun Reader Writes...

Source: (C) The Sun.

Figure 6.2 Bandura's Bobo doll experiment.

Source: (C) Albert Bandura. 
Table 6.1 Criteria of newsworthiness

\begin{tabular}{|c|c|c|}
\hline Galtung and Ruge (1965) & Chibnall (1977) & Jewkes (2011) \\
\hline $\begin{array}{l}\text { Threshold (level of } \\
\text { importance required to } \\
\text { achieve news visibility) }\end{array}$ & & $\begin{array}{l}\text { Threshold (level of } \\
\text { importance required to } \\
\text { achieve news visibility) }\end{array}$ \\
\hline Unexpectedness (novelty) & Novelty (unexpectedness) & \\
\hline $\begin{array}{l}\text { Negativity (violent, harmful, } \\
\text { deviant, sad) }\end{array}$ & & Violence \\
\hline $\begin{array}{l}\text { Unambiguity (clear and } \\
\text { definite) }\end{array}$ & $\begin{array}{l}\text { Simplification (removing } \\
\text { shades of grey) }\end{array}$ & $\begin{array}{l}\text { Simplification (removing } \\
\text { shades of grey }\end{array}$ \\
\hline \multicolumn{3}{|l|}{ Dramatisation (action) } \\
\hline $\begin{array}{l}\text { Frequency (timescale, fit } \\
\text { within news cycle) }\end{array}$ & $\begin{array}{l}\text { Immediacy (the present, fit } \\
\text { within news cycle) }\end{array}$ & \\
\hline \multirow[t]{2}{*}{$\begin{array}{l}\text { Elite-centricity (powerful or } \\
\text { famous nations or people) }\end{array}$} & $\begin{array}{l}\text { Personalization (notable } \\
\text { individuals, celebrities) }\end{array}$ & $\begin{array}{l}\text { Celebrity or high-status } \\
\text { (notable individuals) }\end{array}$ \\
\hline & $\begin{array}{l}\text { Structured Access (experts, } \\
\text { officials, authority) }\end{array}$ & \\
\hline \multicolumn{3}{|l|}{$\begin{array}{l}\text { Composition (balance, fit } \\
\text { with other news) }\end{array}$} \\
\hline $\begin{array}{l}\text { Personification (individual } \\
\text { focus or causality) }\end{array}$ & $\begin{array}{l}\text { Individual pathology } \\
\text { (individual causality) }\end{array}$ & $\begin{array}{l}\text { Individualism (individual } \\
\text { focus or causality) }\end{array}$ \\
\hline \multicolumn{3}{|l|}{ Continuity (sustainability) } \\
\hline & & Children (young people) \\
\hline & Graphic presentation & $\begin{array}{l}\text { Spectacle or graphic } \\
\text { imagery }\end{array}$ \\
\hline & Visible/spectacular acts & \\
\hline $\begin{array}{l}\text { Meaningfulness (spatial } \\
\text { and cultural relevance) }\end{array}$ & $\begin{array}{l}\text { Proximity (spatial and } \\
\text { cultural relevance) }\end{array}$ & \\
\hline Consonance (fit with & Conventionalism & Predictability \\
\hline
\end{tabular}




\begin{tabular}{|l|l|l|}
\hline $\begin{array}{l}\text { existing knowledge and } \\
\text { expectations) }\end{array}$ & (hegemonic ideology) & (expectedness) \\
\hline & $\begin{array}{l}\text { Titillation (exposes, } \\
\text { scandal) }\end{array}$ & Risk (lasting danger) \\
\hline & $\begin{array}{l}\text { Sexual/political } \\
\text { connotations }\end{array}$ & $\begin{array}{l}\text { Sex } \\
\text { political diversion } \\
\text { (deterrence, distraction } \\
\text { from wider problems) }\end{array}$ \\
\hline & Deterrence and repression \\
\hline
\end{tabular}

Sources: Galtung and Ruge (1965); Chibnall (1977); Jewkes (2004). 